\title{
Maryja w Kościele apostolskim w świetle pism Łukaszowych ${ }^{1}$
}

Czytelnik rozpoczynający lekturę dzieła Łukasza Ewangelisty nie jest pewien, z jakimi treściami przyjdzie mu się zmierzyć. W swoim krótkim wstępie do Ewangelii autor wspomina bowiem ogólnikowo o wydarzeniach, które „spełniły się wśród nas” (w. 1) i o świadectwie naocznych świadków (w. 2), a także o katechezach udzielonych adresatom, które jego zdaniem są wiarygodne (w. 4). Dopiero z perspektywy prologu do drugiego tomu dzieła ujawnia się jego szerszy plan. Jak pisze sam Łukasz, Ewangelia została poświęcona Jezusowym czynom i nauczaniu ( $\mathrm{Dz} 1,1)$ aż po moment Jego Wniebowstąpienia (w. 2). We wstępie do Dziejów Apostolskich zostaje również ujawniony dalszy ciąg narracji, która odtąd ma dotyczyć świadectwa Kościoła niesionego „po krańce ziemi” (w. 8). W ten sposób staje się oczywiste, że dzieło Łukasza nie zostało napisane z myślą o Matce Jezusa, a wątki Jej dotyczące są całkowicie podporządkowane centralnemu celowi ewangelisty: ukazaniu realizacji zbawczego planu Boga w Jezusie Mesjaszu i Jego Kościele. Odkrywanie osoby

1 W przeszłości ukazywało się już sporo opracowań na ten temat, z najnowszych warto wspomnieć: B.E. Reid, An Overture to the Gospel of Luke, „Currents in Theology and Mission” 39 (2012) 6, s. 428-434; J. Feník, R. Lapko, Annuciation to Mary in Luke 1-2, „Biblica” 96 (2015) 4, s. $498-524$. 
Maryi w Łk-Dz wymaga zatem stałego odniesienia do szerszej teologicznej perspektywy trzeciego ewangelisty. Rozważania te będą odwoływać się nie tyle do schematu tematycznego zaczerpniętego $z$ teologii systematycznej², ile raczej podążać za myślą trzeciego ewangelisty.

\section{Porządek narracyjny}

Nie ulega wątpliwości, że pierwszoplanowa rola Maryi w Łk-Dz ogranicza się do początkowych dwóch rozdziałów Ewangelii. Pozostałe wzmianki, choć nie bez znaczenia, trudno uznać za przynależne do głównego wątku opowiadania. Łk 1-2 nie pozostawia jednak wątpliwości, że postać Matki Jezusa jest dla trzeciego ewangelisty fundamentalnie ważna i w kluczowy sposób wiąże się z tożsamością jej Syna.

Specjaliści od Łk-Dz od dziesięcioleci zauważali istnienie dwuwątkowego opowiadania Łk 1-4, którego głównymi bohaterami są Jan Chrzciciel i Jezus. Jednak przynajmniej w Ewangelii dzieciństwa (Łk 1-2) ${ }^{3}$ obydwaj protagoniści pozostają w tle historiozbawczych wydarzeń, w których na pierwszy plan wysuwają się ich rodzice. Wykorzystana przez trzeciego ewangelistę hellenistyczna technika opowiadania zwana synkrisis zestawia umiejętnie przodków Jana: Zachariasza i Elżbietę z postacią Matki Jezusa, Maryi. Józef, legalny ojciec Jezusa, w Łukaszowym opowiadaniu pozostaje niemal całkowicie w cieniu swojej małżonki lub stapia się $\mathrm{z}$ nią do postaci bohatera zbiorowego (Łk 1,27; 2,4-54.16.22-24.27.33.39.41-51). W przedstawionym zestawieniu scen niebagatelną rolę odgrywają szczegółowe paralelizmy wypowiedzi bohaterów, które kontrastowo ilustrują ich

2 Zob. M. Rosik, Mariologia, Teologia Nowego Testamentu, t. 1: Ewangelie synoptyczne i Dzieje Apostolskie, red. tenże, Wrocław 2008, s. 283-334.

3 Dalej: ED.

4 Podróż w ramach spisu jest jedyną sceną z ED, w której Józef jest na pierwszym planie (Łk 2,5; por. Łk 4,22). 
postawę wobec zbawczych inicjatyw Boga. Nie ulega wątpliwości, że w poszczególnych scenach dotyczących Maryi ewangelista zawarł głęboki obraz, który wymaga uwzględnienia paraleli rodziców Jana.

\begin{tabular}{|c|c|}
\hline Zachariasz i Elżbieta & Maryja \\
\hline 1. Kapłan i jego żona & 1. Dziewica \\
\hline 2. Sprawiedliwi i prawowierni & 2. Zaślubiona Józefowi \\
\hline 3. Starzy i bezpłodni & 3. Młoda? \\
\hline $\begin{array}{l}\text { 4. Posługa w świątyni (centrum kultu } \\
\text { Izraela - miejsce przebywania }\end{array}$ & $\begin{array}{l}\text { 4. Mieszka w Nazarecie (miejsce } \\
\text { bez znaczenia) }\end{array}$ \\
\hline Jhwh) & 5. Angelofania w ubogim \\
\hline 5. Angelofania w miejscu świętym & domostwie \\
\hline 6. Od lęku do poddania się strachowi & 6. Od lęku do rozważania \\
\hline $\begin{array}{l}\text { 7. Syn będzie wielki i wielka będzie } \\
\text { jego misja }\end{array}$ & $\begin{array}{l}\text { 7. Syn będzie większy i większa } \\
\text { będzie Jego misja }\end{array}$ \\
\hline 8. Pytanie i niewiara & 8. Pytanie $i$ wiara \\
\hline 9. Bierność & 9. Działanie \\
\hline 10. Wiara Elżbiety & 10. Wiara Maryi \\
\hline
\end{tabular}

Ewangelista prezentuje rodziców Jana, których Bóg ma za ludzi sprawiedliwych, w samych superlatywach $(€ k 1,6)$. Nie mają jednak potomstwa i dopiero interwencja Najwyższego zmieni tę sytuację. Wiadomość dotrze do Zachariasza w najświętszym miejscu ludu wybranego - Przybytku Pana.

Kontrast z prezentacją Maryi jest wyraźny. Jej spotkanie dokonuje się w nieznanym nikomu miejscu, a Ona pozbawiona jest pozytywnej charakterystyki. Czytelnik dowiaduje się tylko, że jest dziewicą mieszkającą w Nazarecie ${ }^{5}$, a jej mężem jest Józef. Sytuacja zmienia się wraz z przejęciem inicjatywy przez Bożego posłańca, który znacząco uzupełnia wiedzę czytelnika. Gabriel na-

5 Trzeci ewangelista zdaje sobie doskonale sprawę, że jego czytelnicy nigdy nie spotkali się z nazwą tej miejscowości i tym samym nie wiążą z nią żadnych konkretnych oczekiwań. 
zywa Ją bowiem „obdarzoną łaską" (gr. kecharitōmenē) i zapewnia o Bożej życzliwości (Pan z Toba!). W dalszej części dialogu odsłaniają się przed czytelnikiem kolejne niezwykłości. Maryja „znalazła łaskę u Pana" (w. 30), będzie matką Mesjasza (w. 32-33), który za sprawą Ducha Świętego pojawi się w jej łonie jako Bóg wcielony (w. 35). Kolejny ważny kontrast dotyczy reakcji odbiorców. Lęk na początku towarzyszy obojgu (tarassō, diatarassomai), co jest typową reakcją człowieka w Biblii. Jednakże podczas gdy on poddaje się całkowicie strachowi (w. 12), Ona pokonuje lęk i poszukuje sensu widzenia (dialogidzomai, w. 29). Szczegóły anielskiego objawienia wyraźnie wskazują, że dziewicę z Nazaretu spotkają wydarzenia nieporównywalnie większe od tych, których doświadczą rodzice Jana, a jednak to właśnie Ona wierzy i stara się zrozumieć swoją sytuację, reagując radosnym poddaniem swojego życia Bogu (genoito, w. 38). Koniec scen zestawia bierność Zachariasza z dynamizmem działania Maryi (1,23.39).

Następna scena ukazuje reprezentantki obydwu głównych bohaterów: Jana i Jezusa. Dzięki nim obydwaj spotykają się ze sobą jeszcze w łonach swoich matek. Spotkanie w górach Judy staje się okazją do interwencji Ducha Świętego, który wywołuje radość w nienarodzonym Janie i wprowadza Elżbietę w stan prorockiego uniesienia ${ }^{6}$. Z Jego natchnienia Elżbieta widzi w krewnej „Matkę swojego Pana” (w. 43) i wygłasza podwójne błogosławieństwo Jej stanu i Jej wiary (w. 42.45).

Maryjny wątek pierwszego rozdziału Ewangelii Łukasza dopełnia radosny hymn poświęcony wielkości i dobroci Boga. Jego pierwsza część zawiera też istotne informacje o Matce Jezusa.

6 Tina Pippin przyznaje tożsamość prorocką nie tylko Elżbiecie, ale i Maryi, akcentując elementy prorockiej wyroczni w hymnie Magnificat, zob. T. Pippin, The Politics of Meeting. Women and Power in the New Testament, w: That They Might Live. Power, Empowerment, and Leadership in the Church, red. M. Downey, New York 1991, s. 13-24. Podobnie widzi to E.A. Johnson, Truly our Sister. A Theology of Mary in the Communion of Saints, New York-London 2003, s. 305-308. 
Wprowadzenie Magnificat odsłania narracyjny pomost ze sceną zwiastowania. Nieznana nikomu dziewczyna z nic nieznaczącej osady czyni Boga wielkim (megalynō, w. 46), ponieważ On uczynił jej wielkie rzeczy (megala, w. 49). W życiu Maryi dokonało się historiozbawcze odwrócenie porządku, którego doświadczy również cały Izrael. Pokorna sługa Boga będzie odtąd nazywana błogosławioną przez wszystkich (w. 48), a jej wywyższenie jest realizacją obietnic Bożych danych patriarchom.

Łk 2 przynosi nowe informacje o Matce Jezusa. Konieczność udziału w spisie ludności zaprowadziła młodych małżonków do Betlejem, gdzie w trudnych warunkach narodził się Jezus $(2,7)$. Słowa aniołów i pasterzy przekonują czytelników, że zapowiedziane wydarzenia zbawcze się realizują: Pan, Zbawiciel i Mesjasz przyszedł na świat $(2,11)$, a tym samym Jego Matka jest Matką Mesjasza, Pana i Zbawiciela. W ostatnim zdaniu tej sceny Łukasz zaznacza, że te wydarzenia stały się przedmiotem rozważań Maryi (symballō, 2,19) i były przez Nią pilnie zachowywane (syntēereō) w pamięci.

W kolejnych scenach zostaje przypomniana żydowska tożsamość rodziny Jezusa, zgodnie z którą ta wypełnia wszystkie zobowiązania wobec Prawa: obrzezanie $(2,21)$ i ofiarowanie w Świątyni (2,22-24) ${ }^{7}$. Łukasz już przy okazji hymnu Magnificat dał poznać czytelnikom, że Maryja przeżywa swoje wybranie jako członek żydowskiej społeczności wiary $(1,55)$. Spotkanie z Symeonem ukazuje nowy aspekt tajemnicy Maryi. Jej Syn będzie zbawieniem dla wszystkich ludzi (2,30-32), co budzi Jej zdziwienie (thaumadzō), a Ją samą czeka przyszłość pełna bolesnych doświadczeń $(2,35)$.

Ostatnia scena ED ponownie podkreśla żydowską tożsamość rodziny Jezusa. Józef i Maryja co roku biorą udział w pielgrzymce do Jeruzalem na święto Paschy $(2,41)$. Chrystologiczny charakter

7 Działania Maryi i Józefa legitymizują tożsamość Jezusa. Tylko będąc członkiem ludu wybranego włączonym w Przymierze z Bogiem, może On podjąć misję Mesjasza. 
tej sceny jest oczywisty, ale zawiera ona również cenne informacje o Maryi, ponieważ godność i przymioty Syna zostają w niej skonfrontowane z kondycją Jego rodziców. Maryja z Józefem nie panują nad sytuacją. Najpierw tracą Jezusa z pola widzenia, ponieważ On postanowił zatrzymać się dłużej w Świątyni, a później przez trzy pełne cierpienia (odynaomai, 2,48$)^{8}$ dni usiłują Go znaleźć. Kulminacyjna wypowiedź Jezusa o Jego więzi z Ojcem ujawnia ważną kwestię: obydwoje (Maryja także!) nie rozumieją tego, co się stało. Retoryczne pytanie Jezusa: „Czy nie wiedzieliście?” $(2,49)$, zakłada bowiem odpowiedź negatywną: nie wiedzieli.

Dwie kolejne sceny z głównego toku narracji pierwszego tomu dzieła Łukasza mają różny charakter. Pierwsza, z tradycji Markowej, jest świadomym zestawieniem pokrewieństwa z nowym rodzajem więzi, które zainicjował Jezus, głosząc królestwo. Bliscy Jezusa, wraz z Matką, zostają w niej ukazani jako Ci, którzy nie mają do Niego dostępu, ponieważ nowy rodzaj więzi polega na słuchaniu słowa Bożego i jego wypełnianiu (8,21), co współgra z przedstawioną wcześniej postawą Maryi (1,29; 2,19.51). Podobną wymowę ma okrzyk nieznanej kobiety $(11,27)$ będący spontaniczną pochwałą więzów krwi między Jezusem a Jego Matką. Mistrz kieruje jednak uwagę swoich słuchaczy na więź polegającą na wiernym słuchaniu i zachowywaniu słowa $(11,28)$, która od początku jest udziałem Maryi, co stawia w nowej perspektywie więź pomiędzy Nimi.

Dopełnieniem scen z Ewangelii jest krótka wzmianka o obecności Maryi wśród modlącego się Kościoła czekającego na dar Ducha Świętego. Paralele pomiędzy rolą Ducha Świętego w Jej życiu (1,35), początku misji Jezusa na Jordanem (3,21-22) i inauguracją misji Kościoła (Dz 2) świadczą o tym, że Jej obecność nie jest przypadkowa. Nie bez znaczenia jest także silne powiązanie tajemnicy eucharystycznej i Zesłania Ducha Świętego poprzez miejsce Wieczernika (Łk 22,7-38; Dz 1,12-2,47).

8 Intensywność tego czasownika podkreśla jego użycie w innych miejscach dzieła (Łk 16,24-25; Dz 20,38). 


\section{Charakterystyka postaci}

Wszystkie przedstawione powyżej sceny zawierają liczne elementy pozwalające wydobyć charakterystyczne cechy postaci Maryi. Ich analiza $\mathrm{w}$ powiązaniu $\mathrm{z}$ narracyjnym kontekstem pozwoli docenić mariologiczne aspekty dzieła Łukaszowego. $Z$ pewnością trudno będzie je uznać za systematyczną uporządkowaną teologię, ale poszczególne jej wymiary pozwolą odkryć treści, które leżą u podstaw współczesnej mariologii ${ }^{9}$.

W swoim znakomitym studium poświęconym charakterystyce postaci Nowego Testamentu Cornelis Bennema zaproponował schemat, który ułatwia przeprowadzenie systematycznego badania poszczególnych postaci biblijnych ${ }^{10}$. Stosując jego schemat do postaci Maryi w Łk-Dz, można przygotować następujące zestawienie:

\begin{tabular}{|l|l|}
\hline \multicolumn{2}{|c|}{ Mariam - Matka Jezusa } \\
\hline Obecność w opowiadaniu & $\begin{array}{l}\text { Łk 1,26-38; 1,39-45; 2,1-51; 8,19-21; } \\
\text { 11,27-28; Dz 1,14 }\end{array}$ \\
\hline Pochodzenie & $\begin{array}{l}\text { Data i miejsce narodzenia nieznana }{ }^{11} \text {, żydow- } \\
\text { ska dziewczyna (dziewica), mieszkanka Galilei } \\
\text { (Nazaret) }\end{array}$ \\
\hline & Klan Maryi mieszkający w Nazarecie (?) \\
\hline Wychowanie & Żydowskie wychowanie społeczno-religijne \\
\hline
\end{tabular}

9 Panoramę przemian zachodzących w katolickiej mariologii z perspektywy Kościoła amerykańskiego czytelnik znajdzie w opracowaniu J.J. Tibbetts, Historical Developement of Biblical Mariology Pre-and Post-Vatican II, Dayton 1995.

10 C. Bennema, A Theory of Character, Minneapolis 2014, s. 111.

${ }^{11}$ Informacje z Protoewangelii Jakuba, będącej apologią Jezusa i Maryi w odpowiedzi na żydowski paszkwil Toledot Jeszuh, trudno uznać za historyczne tło postaci Matki Jezusa; por. M. Starowieyski, Kulturotwórcza rola apokryfów, w: Idee chrześcijańskie w życiu Europejczyka, red. A. Ceglińska, Z. Staszewska, Łódź 2001, s. 63-76. 


\begin{tabular}{|l|l|}
\hline Dobra zewnętrzne & Określenia \\
& Narrator: \\
& Dziewica z Nazaretu w Galilei, zdolna rozwa- \\
& żać tajemnice w obecności Boga, zdolna dialo- \\
gować z Bogiem & Maryja: \\
& Poszukująca zrozumienia Bożych planów („Jak \\
& to się stanie?”), gotowa spełnić wolę Boga (ge- \\
& noito), szukająca zrozumienia działań Jezusa \\
& („Czemu tak wobec nas postąpiłeś?”) \\
& Anioł/aniołowie: \\
& Obdarowana łaską, Pan jest z Nią, błogosła- \\
& wiona wśród kobiet, znalazła łaskę u Boga, jest \\
& Matką Mesjasza, Pana i Zbawiciela, poczęła \\
bez udziału mężczyzny za sprawą Ducha Świę- & tego, Jej Syn jest Bogiem \\
& Inni bohaterowie opowiadania: \\
& Elżbieta: błogosławiona, która uwierzyła; Mat- \\
ka Pana & Symeon: doświadczy cierpienia, co ujawni \\
& wnętrza wielu \\
Nazaretanie: Ona i Jej bliscy wstępni nie wsła- \\
wili się niczym szczególnym (Łk 4,22) \\
Nieznana kobieta: Błogosławiona jako fizycz- \\
na matka Jezusa \\
Popaschalny Kościół: uważa Ją za istotną po- \\
stać w swojej społeczności \\
\hline Nastolatka, zamężna (przed ceremonią prze- \\
niesienia się do domu męża) \\
\hline Uboga dziewczyna, brak informacji o posiada- \\
nych dobrach materialnych \\
\hline
\end{tabular}




\begin{tabular}{|l|l|}
\hline & $\begin{array}{l}\text { W Łk-Dz obecna w Nazarecie, En Karem, Be- } \\
\text { tlejem i Jeruzalem. Przesłanki z Ewangelii } \\
\text { Jana o Jej przynajmniej częściowej obecności } \\
\text { podczas misji Syna (Kana) i w momencie Męki } \\
\text { (J 19) }\end{array}$ \\
\hline Bez zawodu i szczególnych funkcji społecz- \\
nych, matka i opiekunka Jezusa \\
\hline Związana z własnym klanem (Łk 4,22; \\
Mk 6,3), mieszkańcami Nazaretu, żona Józe- \\
fa z rodu Dawida. Obecna u początków życia \\
pierwotnego Kościoła jako członek wspólnoty \\
wiary. Brak informacji o przyjaciołach
\end{tabular}




\begin{tabular}{|l|l|}
\hline & Życie wewnętrzne: \\
& opanowanie \\
& refleksyjność \\
& zrozumienie \\
& wiara \\
& ufność \\
& posłuszeństwo \\
& pamięć \\
& gotowość do dojrzewania \\
& lęk \\
& niezrozumienie \\
& zdumienie \\
& wewnętrzna walka/cierpienie \\
\hline Klasyfikacja postaci & Stopień charakterystyki: \\
& Krótka, chociaż bogata charakterystyka po- \\
& staci. Szereg elementów zewnętrznych i we- \\
& wnętrznych. Nieobecność w większości wąt- \\
ków dzieła Łukasza.
\end{tabular}




\begin{tabular}{|l|l|}
\hline Znaczenie postaci & Wartość charakterystyczna postaci: \\
& Obdarowana przez Boga \\
& Zaproszona do udziału w Jego planach - ma- \\
& cierzyństwo \\
& Ta, która uwierzyła \\
& Uczennica/sługa Pana \\
\hline
\end{tabular}

\section{Tożsamość Maryi jako konsekwencja Bożych działań}

Łukaszowe opisy ED w sposób wyraźny akcentują inicjatywę Boga wobec Maryi, co podkreśla przede wszystkim treść anielskiego orędzia ze sceny zwiastowania. Pierwszym jej elementem jest obdarowanie Jej szczególnymi łaskami, a drugim zapowiedź niezwykłej godności, którą Ją Bóg obdarzy - macierzyństwem Mesjasza, Syna Bożego.

\section{Obdarzona łaskq}

Scena zwiastowania buduje poprzez orędzie Gabriela obraz Maryi, która została ogarnięta łaską. Łukasz posługuje się w niej rzadkim w Piśmie Świętym określeniem kecharitōmenē, które najczęściej za Wulgatą (łac. gratia plena) jest w polskich tłumaczeniach oddawane przez „pełna łaski” (Łk 1,28). Oprócz tego określenia anioł zapewnia przyszłą Matkę Mesjasza, że jest przedmiotem szczególnej życzliwości ze strony Boga, co wyraża starotestamentowa fraza „znaleźć łaskę u Boga” (Łk 1,30)12. Greckie kecharitōmenē nie zostało wiernie przekazane we wszystkich wczesnochrześcijańskich tłumaczeniach. Te przekłady, które trzymają się ściśle czasownikowej formy perfectum od charitoō, zachowują jego imiesłowowy charakter i tłumaczą je na łacinę

12 Można ją znaleźć w wielu miejscach Starego Testamentu, zob. np. Rdz 6,8. 
gratificata (codex Palatinus i q), ale trzeba przyznać, że jest ona rzadko obecna w łacińskich przekładach ojców Kościoła.

Forma kecharitōmenē występuje zaledwie raz w Biblii greckiej i w Nowym Testamencie. Księga Syracha stosuje ją do człowieka, który łączy dobre dary z dobrym słowem (Syr 18,17). Natomiast sam czasownik charitoō poza dziełem Łukasza występuje w Ef 1,6. W tym wypadku użyta forma ma jednak stronę czynną i odnosi się do Boga udzielającego łask wierzącym w Chrystusa ${ }^{13}$. Imiesłów bierny czasu perfectum dotyczy konkretnej czynności dokonanej, której skutki obejmują teraźniejszość i przyszłość ${ }^{14}$. Obdarzenie łaską Maryi powinno być zatem rozważane w kategoriach trwałej przemiany, która nastąpiła uprzednio w stosunku do wydarzenia angelofanii opisanej przez Łukasza. Inaczej mówiąc, Bóg dokonał uprzedniej interwencji w życiu Maryi, a scena zwiastowania jest kontynuacją sekwencji zbawczych wydarzeń ${ }^{15}$.

Sceny z Zachariaszem i Maryją ujawniają pewną istotną różnicę w postawie anioła. Angelofanię Maryi wprowadza wezwanie do radości (chaire $)^{16}$ i zapewnienie o Bożej życzliwości („Pan jest z Tobą!") połączone z określeniem Maryi kecharitōmenē (Łk 1,28). Imię zastąpione imiesłowem przywołuje na pamięć scenę powołania Gedeona ( $\mathrm{Sdz} 6,11-24)^{17}$. Podobnie jak w dziele

13 Por. znaczenie czasowników o końcówce -oō, np.: leukoō - wybielić; douloō - zniewolić; zob. R. Popowski, Wielki słownik grecko-polski Nowego Testamentu, Warszawa 1995, s. 652.

14 M. Zerwick, Biblical Greek Illustrated by Examples, Rome 1963, s. 96.

15 Forma perfectum nie pozwala jednak przesuwać tego momentu zbyt daleko w przeszłość. Tak widzi to również J.A. Fitzmyer, The Gospel according to Luke I-IX: Introduction, Translation, and Notes, [AYB 28A], New Haven-London 2008, s. 345-346. Łukasz skupia się na zwiastowaniu, a ojcowie Kościoła rozszerzają jego rozumienie.

16 Greckie chaire było standardową formułą pozdrowienia. We współczesnym języku polskim jej odpowiednikiem jest: Witaj.

17 Podobną trzyelementową strukturę przyjmują także inne opisy powołań (Jr 1,4-8; Iz 6; Ez 1-3): po wprowadzeniu (w. 4), jest (1) wybór 
Łukaszowym bohaterem spotkania z Bogiem jest mało znacząca postać $z$ ubogiej osady. Podobne są słowa pozdrowienia: „Pan jest z Tobą!”, a zamiast imienia pada określenie odbiorcy: „dzielny wojowniku". Obydwie sceny składają się również ze zwartego przekazu anielskiego posłania ( $\mathrm{Sdz} 6,14$; por. Łk 1,30-33), wątpliwości odbiorców (Sdz 6,15; por. Łk 1,34) i stosownego wyjaśnienia (Sdz 6,16-24; por. Łk 1,35-37). W każdej z nich wspomina się o Bożej pomocy i o znaku umocnienia wiary odbiorcy (Sdz 6,16-17; Łk 1,35-37).

Nowy stan Maryi - „bycie obdarowanym łaską” ma swój wyraz w jej osobistej modlitwie. Wyśpiewując hymn Magnificat odwołuje się bowiem do wielkich rzeczy (megala), które jej Pan uczynił (Łk 1,49), a które skłaniają ją do czynienia wielkim Boga (magalynō, Łk 1,46). Swoje wywyższenie uważa za kolejny element planu Zbawiciela, który dokonywał wielkich znaków w przeszłości, a obecnie dopełnia swój plan, realizując obietnice dane patriarchom (Łk 1,55).

Orędzie anioła dopełnia zapewnienie Gabriela, że Maryja znalazła łaskę u Boga. Użyta przez ewangelistę forma aorystu wskazuje na pojedyncze wydarzenie z przeszłości. Podobnie jak w obrazach starotestamentowych formuła ta oznaczała szczególną Bożą życzliwość (Rdz 6,8; 18,3; 19,19; Wj 33,12; 2 Sm 15,25) i odnosiła się do kluczowych postaci w historii zbawienia, co stawia Matkę Jezusa w gronie największych przedstawicieli ludzkości, którzy uczestniczyli w realizacji Bożych planów.

\section{Zaproszona do udziału w planach Boga}

Całość anielskiego orędzia wyraźnie podkreśla inicjatywę po stronie Boga, który uprzednio obdarował Ją łaską i zaprasza do udziału w swoich zbawczych planach. Została wybrana, by stać

i powierzenie misji (ww. 5-6), dalej (2) obiekcje powołanego (w. 7) oraz (3) zapewnienie o Bożej asystencji (w. 8); por. też Wj 3-4; Sdz 6,11-17; $1 \mathrm{Sm} \mathrm{9,17-10,7.}$ 
się matką. Pocznie i urodzi syna, Jezusa (Łk 1,31) ${ }^{18}$, który będzie wielki (megas $)^{19}$, ponieważ zrealizuje obietnice dane Dawidowi (2 Sm 7,12-14). Maryja zostanie zatem matką Mesjasza, który będzie się cieszył szczególną więzią z Bogiem, „będzie nazwany Synem Najwyższego" (Łk 1,32).

Macierzyństwo Maryi odniesione do mesjańskiej godności Jej Syna jest najbardziej oczywistą realizacją oczekiwań wyznawców judaizmu. Spełnione proroctwa, o których sama wspomina w hymnie Magnificat, zainaugurują eschatologiczną erę odnowienia Izraela i ostatecznej rozprawy z Jego wrogami ${ }^{20}$. Przyszły Mesjasz narodzi się w Betlejem (Mi 5,1-2), co Łukasz zabezpiecza spisem ludności (Łk 2,1-4). Od zwiastowania wiadomo też, że zrealizuje się wyrocznia proroka Natana (1 Sm 7,12-14). Pytanie Maryi w kolejnym wersecie (Łk 1,34) prowokuje jednak głębsze odsłonięcie tajemnicy i wynika z niego, że Jej potomek znajdzie się w Jej łonie bez udziału mężczyzny i przy szczególnej asystencji Ducha Świętego (Łk 1,35). W tym kontekście nie można określenia Syn Boży traktować już tylko jako starotestamentowego odniesienia do Bożych wybrańców (Wj 4,22; Oz 11,1; Jr 31,9; Ps 82,6). Sytuacja przychodzącego na świat Jezusa jest wyjątkowa, a tym samym jego Matka jest prawdziwie Matką Syna Bożego. Dzieło Łukaszowe w żadnym miejscu nie używa określenia Bogurodzica (Theotokos), ale orędzie Gabriela daje z pewnością mocne podstawy do tego tytułu.

18 H. Verwehen, Mariologie als Befreiung. Lk 1,26-45.56, „Zeitschrift für katholische Theologie”, 105/2 (1983), s. 173, widzi tu aluzję do sceny anioła z Hagar (Rdz 16,11).

19 Ten motyw wskazuje, że wielkie „rzeczy” (megala), za które Maryja czyni Boga wielkim, nie muszą odnosić się tylko do zbawczych wydarzeń w ogólności, ale również do samego Jezusa.

20 Zestawienie własnych losów z losami uciśnionych i ubogich, których Bóg wyniesie ku pełni, może również być potraktowane jako echo Gabrielowego kecharitōmenē, ponieważ przypomina o ubogim pochodzeniu Maryi, która ostatecznie będzie nazywana błogosławioną przez wszystkie pokolenia; por. E.A. Johnson, Truly our Sister, 266. 
Takie rozumowanie wspiera bliższa analiza opisu odnoszącego się do działania Ducha Świętego wobec przyszłej Matki Jezusa. Tekst Ewangelii mówi o „przychodzeniu na” (eperchomai) i „osłonieniu" (episkiadzō), co odsyła czytelnika do starotestamentowej idei Opatrzności (Ps 90,4 LXX) i wędrówki Izraelitów przez pustynię (Wj 40,35). Tam obłok chwały Boga Izraela ${ }^{21}$ okrył namiot spotkania, wypełniając go swoją obecnością. W trzeciej Ewangelii ta sama Boża obecność dokonała aktu stworzenia w łonie Maryi. Maryja po uprzednim przygotowaniu (kecharitōmenē) przyjęła Boga-Człowieka w swoim łonie, stając się Przybytkiem Nowego Przymierza.

Scena nawiedzenia zdaje się podążać w tym samym kierunku. Tam również spotkanie dokonuje się przy aktywnej obecności Ducha Świętego, który inspiruje Elżbietę do nazwania Maryi "Matką mojego Pana” (Łk 1,43). Trzeci ewangelista zapowiada w ten sposób chwałę Jezusa, która objawi się po dopełnieniu przez Niego misji (Łk 24,34; por. Dz 2,36), kiedy Zmartwychwstały objawi się jako Kyrios w pełnym sensie tego słowa. Podobny proleptyczny charakter ma orędzie aniołów o tym, że w Betlejem narodził się Zbawiciel, Mesjasz i Pan (Kyrios, Łk 2,11). Aniołowie potwierdzają zatem to, co z natchnienia Ducha Świętego wypowiedziała wcześniej Elżbieta. Maryja prawdziwie jest "Matką Pana”.

Łukaszowe opowiadanie z oczywistych względów akcentuje cudowne macierzyństwo Maryi. Scenę zwiastowania wprowadza jednak informacją o dziewiczym stanie Maryi (parthenos), łącząc ją jednocześnie z przekazem o byciu żoną Józefa (Łk 1,27). W trakcie dialogu z Gabrielem staje się jasne, że zapowiedziane macierzyństwo nie zniesie Jej dziewictwa, ponieważ obiecany potomek zamieszka w Jej łonie za sprawą interwencji Boga (Łk 1,35). Mariologiczna refleksja pierwszych wieków chrześcijaństwa uczyniła virginitas istotnym wymiarem tożsa-

${ }^{21}$ Tamże, 252. 
mości Matki Jezusa Chrystusa. Jednak Łukaszowa refleksja nie sięga poza ochronę tożsamości przyszłego Mesjasza. Dlatego najbardziej oczywistym wymiarem dziewictwa Maryi w dziele trzeciego ewangelisty jest Jej stan do momentu narodzin Jezu$\mathrm{sa}^{22}$. Czytelnik dzieła powinien bowiem wiedzieć, że Jezus nie ma ziemskiego ojca w sensie biologicznym, ponieważ Józef jest ojcem jedynie de iure, ale nie de facto (hōs enomizeto, Łk 3,23). Tym samym macierzyństwo Maryi jest w sposób cudowny naznaczone także stanem dziewiczym.

Zwolennicy rozszerzenia podstaw dziewiczego stanu Maryi w tradycji biblijnej wskazują na kluczowe ich zdaniem pytanie w scenie zwiastowania, wskazujące na Jej brak kontaktu seksualnego z mężczyzną (Łk 1,34) ${ }^{23}$. Treść tego pytania stosunkowo trudno jest wytłumaczyć. Carmelo Pelegrino postanowił znaleźć rozwiązanie, stosując metodę narracyjną ${ }^{24}$. Zauważając wagę tekstów nawiązujących do postaci Maryi w dalszej części dzieła (Łk 8,19-21; 11,27-28), podkreśla, że podejmują one temat więzów krwi w kontekście wspólnoty bliskich Jezusa. Jezus wskazuje tam nową logikę bliskości, która zgodnie z Jego Ewangelią

${ }^{22}$ Część Kościołów poreformacyjnych odrzuca stan dziewiczy Maryi po urodzeniu Jezusa, powołując się na wzmianki o Jego braciach i siostrach (Mt 13,55-56). Egzegeza katolicka proponuje rozumienie tej tradycji w sensie szerszej rodziny, czyli klanu, co oznaczałoby, że wspomniane rodzeństwo byłoby de facto kuzynostwem. Natomiast autor Protoewangelii Jakuba stara się zabezpieczyć prawdę o dziewictwie Maryi, informując o podeszłym wieku Józefa, który miał poślubić Maryję, będąc już wdowcem i mając własne dzieci (PJk 9,1-3).

23 Tak powszechnie odczytuje się sens pytania Maryi, która z legalnego punktu widzenia jest już zamężna; zob. J.A. Fitzmyer, The Gospel according to Luke I-IX, s. 52-54.

24 C. Pellegrino, Maria di Nazaret, Profezia del Regno. Un approccio narrativo a Lc 1,34, Roma 2014. Chciałem jednocześnie wyrazić wdzięczność ks. Adamowi Kubisiowi, który nie tylko zwrócił mi uwagę na tę monografię, ale również udostępnił własny materiał z przygotowywanego artykułu na ten temat. Czytelnik znajdzie tam szeroką prezentację dyskusji naukowej na temat Łk 1,34. 
ma polegać na wiernym słuchaniu i zachowywaniu Słowa. Czytelnik zostaje tym samym zmuszony do przywołania postawy Maryi z ED, która to postawa była całkowitym i bezwarunkowym zawierzeniem Bogu i uważnym gromadzeniem w pamięci Jego inicjatyw, aż po obecność wśród uczniów oczekujących na obietnicę Ojca (Dz 1,14). Jest ona znakiem, że Maryja przyjęła logikę Ewangelii, podejmując płodność duchową w miejsce biologicznej.

\section{Odpowiedź Maryi na działanie Boga}

Łukaszowych opisów na temat Matki Jezusa nie da się sprowadzić tylko do wymiaru Bożych inicjatyw. Pierwszeństwo Jego łaski i zbawczych planów nie ulega dla ewangelisty żadnej wątpliwości. Jednakże aktywność Maryi w dialogu z Bogiem jest również zaznaczona bardzo mocno. W schemacie narracyjnym w początkowym fragmencie artykułu odkryte zostały dwa wymiary tej aktywności, które w dużej mierze się pokrywają. Pierwszy został najlepiej podsumowany w scenie nawiedzenia w słowach wypowiedzianych z natchnienia Ducha Świętego przez Elżbietę: „Błogosławiona, która uwierzyła” (Łk 1,45). Maryja jest człowiekiem wiary. Osobą, która z ufnością przyjmuje ofertę Boga. Akt radosnego, pełnego energii zawierzenia w obecności anioła Gabriela nie zakończył jednak drogi wiary Maryi. Kolejne jej etapy zostały zarysowane w następnych scenach ED aż po wzmiankę z Dziejów Apostolskich (1,14). Droga ta jest na tyle bogata, że można ją uznać za rodzaj szkoły ucznia Chrystusowego ${ }^{25}$, poprzez którą ewangelista zaprasza swoich czytelników do naśladowania doświadczeń Maryi.

25 Podobnie widzi to E.A. Johnson, Truly our Sister, s. 247. 


\section{Błogosławiona, która uwierzyła}

W scenie zwiastowania ani słowo „wiara”, ani czasownik „uwierzyć" nie pada ani razu. Paralela zwiastowania Zachariasza i obecna tam niewiara wywołuje w czytelniku napięcie co do rezultatu wizyty anioła w Nazarecie. Cała scena kończy się jednak pełną entuzjazmu zgodą Maryi na uczestnictwo w Bożych planach (genoito, Łk 1,38) ${ }^{26}$. To, co zostało negatywnie potwierdzone w przypadku Zachariasza, zostaje u Maryi przeniesione do kolejnej sceny, gdzie narrator informuje ustami Elżbiety, że Maryja uwierzyła i dlatego jest błogosławiona (Łk 1,45).

Posłuszeństwo wiary w scenie zwiastowania zostało wyrażone prostą formułą: „Jestem służebnicą Pana”, uzupełnioną wolą, by słowa Pana się spełniły. Określenie służebnica (doulē) pojawia się jeszcze raz w Magnificat, gdzie dodatkowo Maryja mówi o swoim „uniżeniu” (tapeinōsis, por. Dz 8,33). W ten sposób Łukasz łączy Magnificat z Iz 58,3. Możliwe jest także znaczenie metaforyczne, wskazujące na świadomość Bożej transcendencji i własnej kruchości. Maryja należy bowiem do „ubogich Pana”, którzy znajdują się pod szczególną Bożą opieką ${ }^{27}$.

\section{Maryja w szkole Boga i Jego Syna}

Przyjęcie Bożego orędzia i wiara w jego spełnienie ukazane w scenie zwiastowania nie jest jednorazowym aktem, wskazującym na jakąś statyczną cechę opisywanej postaci. Łukasz opisując po-

${ }^{26}$ E.A. Johnson (tamże, s. 256-257) widzi w wypowiedzi Maryi paralelę do zgody Izajasza w scenie powołania lub innych proroków i przypisuje Łukaszowi intencję ukazania wiejskiej dziewczyny jako prorokini.

27 F. Bovon, Luke 1: A Commentary on the Gospel of Luke 1:1-9:50, Minneapolis 2002, s. 61. Środowiska feministyczne widzą w hymnie Maryi przede wszystkim paradygmatyczną scenę dotyczącą wszystkich uciśnionych i zmarginalizowanych; zob. J.D. Schaberg, Luke, Women's Bible Commentary, red. C.A. Newsom, S.H. Ringe, Louisville $2012^{3}$, s. 284. 
stawę Maryi, używa czasowników, które pozwalają czytelnikowi odkryć, że jest Ona modelowym przykładem ucznia: słuchanie i rozważanie (dialogidzō, Łk 1,29), pamięć (syntēreō, Łk 2,19) i wewnętrzny namysł (symballō, Łk 2,19).

Wprawdzie czasownik akouō nie pojawia się $\mathrm{w}$ odniesieniu do Maryi, ale jej postawa słuchania została przedstawiona techniką showing ${ }^{28}$. Łukasz wprowadza postawę słuchania Maryi, posługując się szerszym kontekstem. Dopiero dalsza aktywność przyszłej Matki Jezusa ukazana jest konkretnymi czasownikami (telling). Ta zawoalowana informacja stanie się później podstawą retorycznego apelu do czytelnika w głównej części narracji ewangelicznej. Markowa tradycja o nowej rodzinie Jezusa, „która słucha słowa Bożego i wypełnia je" (Łk 8,21), zyskuje nowy mariologiczny aspekt. Czytelnik jest wezwany, by zaliczył Maryje do bliskich Jezusa nie z powodu więzów krwi, ale ze względu na Jej postawę wiernego słuchania Słowa (por. Łk 11,27-28). Czasowniki syntēreō/diatēreō/fylassō (zachowywać/strzec) uzupełniają ten obraz.

Dwa kolejne czasowniki wyrażające ideę roztrząsania zbawczych wydarzeń pogłębiają tylko wcześniejsze intuicje o Maryi zaangażowanej w dialog z Bogiem. Łukasz dodatkowo podkreśla w ten sposób ludzką naturę Dziewicy z Nazaretu, która nie nosi w sobie boskiej zdolności rozumienia wszystkich spraw, ale dzięki wierze i gotowości serca jest w stanie wejść na drogę stopniowego jej odkrywania (Łk 1,29; 2,19). Angażuje się całą sobą w wydarzenia, w których uczestniczy, i chce podjąć ich ciężar i znaczenie. Dowodem na to, że Bóg nie objawia Jej wszystkiego od samego początku ${ }^{29}$, jest Jej naturalna reakcja zdumienia (thaumadzō, Łk 2,33) wobec tego orędzia Symeona o Jezusie,

28 Na temat techniki telling i showing zob. M.H. Abrams, A Glossary of Literary Terms, New York 1981, s. 20.

29 Temat ten podejmowali również w przeszłości amerykańscy bibliści w ramach uzgodnień ekumenicznych, zob. Mary in the New Testament, red. R.E. Brown, K.P. Donfried i in.; Mahwah 1987, s. 150-151. 
a także jego zapowiedź doświadczeń, które będzie musiała przejść w przyszłości. Proroctwo Symeona wspomina o mieczu (romfaia), który przeniknie Jej duszę $e^{30}$, co zapowiada trudne doświadczenia.

Obraz Maryi w szkole Boga i Jego Syna nie został porzucony w tym dramatycznym momencie. Ewangelista dopełnia go obecnością Matki Pana we wspólnocie Kościoła w Jeruzalem, która trwając na modlitwie, czeka na obietnicę Ojca, aby rozpocząć misję świadectwa o Zmartwychwstałym (Dz 1,14). Nie ma wątpliwości, że jest to wyraźny sygnał dla czytelnika, że Maryja osiągnęła cel swojej uczniowskiej drogi. Wraz z apostołami podjęła naukę swojego Syna i w wierze zmierzała ku jej ostatecznemu spełnieniu ${ }^{31}$. Maryja modląca się z Kościołem popaschalnym jest dopełnieniem, przywołuje ponownie sceny z ED, gdzie Matka Jezusa zaczyna swoją drogę modlitwy indywidualnej (Łk 1,46-55) i zbiorowej (Łk 2,22-39).

Przedstawiona wyżej panorama tekstów biblijnych i ich interpretacji z pewnością daleka jest od kompletności. Narracyjne podejście do Łukaszowych tekstów pozwoliło jednak wyłowić główne wątki teologiczne, które składają się na przekaz trzeciego ewangelisty. Na podstawie przedstawionych analiz można stwierdzić, że zaproponowany przez Łukasza obraz Maryi sprowadza się do dwóch podstawowych wymiarów: Bożego obdarowania wyrażonego w duchowym imieniu Maryi - kecharitōmēne, i jej bezpo-

30 Określenie dusza (psyche) pojawiło się już wcześniej w powiązaniu z radością i uwielbieniem (Łk 1,46-47).

31 Tradycja katolicka, a zwłaszcza ikonografia, wykazuje tendencję do ograniczenia reprezentacji w dniu Pięćdziesiątnicy do grona apostołów i Maryi. Jednak Łukasz, eksponując obecność Maryi i dwunastu, sugeruje znacznie szerszą obecność uczniów, w tym również kobiet i braci Jezusa. Zostaje nawet wymieniona konkretna liczba uczestników zgromadzenia, która wynosiła około stu dwudziestu osób (Dz 1,14-15). 
średnim udziale $\mathrm{w}$ historii zbawienia przez macierzyństwo oraz aktywnej odpowiedzi Maryi wyrażonej w konsekwentnej wierze, która z czasem stała się drogą ucznia Chrystusa. Te dwa aspekty są istotną częścią fundamentu biblijnej mariologii, na którym ufundowana została wiara pierwotnego Kościoła i kolejnych pokoleń chrześcijan.

\section{Mary in the Apostolic Church in the light of the Lukan Writings}

Lukan Mariology does not present a holistic picture of Jesus' Mother, although no doubt it is fundamentally important for the narrative of Luke-Acts. The Infancy Narrative and the three further traditions disseminated in the main bulk of the Lukan work (Lk 8:21; 11:27-28; Acts 1:14) show that her person cannot be limited to her faith or motherhood only. The author of the third Gospel composed a careful set of scenes in order to share with his readers much fuller picture of Mary. Being a Mother of the Lord, she is also a disciple following God's will and the teaching of her Son. 